Copyright (C) 2017 by Academic Publishing House Researcher

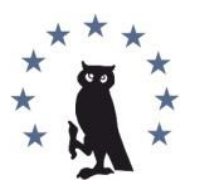

Published in the Russian Federation

European Researcher. Series A

Has been issued since 2010.

ISSN 2219-8229

E-ISSN 2224-0136

2017, 8(2): 58-62

DOI: 10.13187/er.2017.2.58

www.erjournal.ru

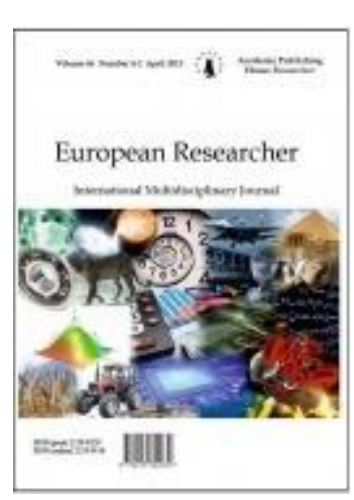

UDC 7.01

\title{
Azerbaijan's Medieval Clothes and Jewelry
}

Yegana Aghamaliyeva ${ }^{a},{ }^{*}$

a Azerbaijan State University of Economics, Baku, the Republic of Azerbaijan

\begin{abstract}
In the $16^{\text {th }}$ century high level of culture and art has positively influenced the development of clothing in Azerbaijan. In the $17^{\text {th }}$ century in spite of paleness of manufactured fabric and its ornaments, clothing style completely reminds $16^{\text {th }}$ century clothes. $18^{\text {th }}$ century clothes distinguish with its high level of form and composition.

In that period clothes were decorated by sewing. Traditional clothing set was completed by jewelries considered for neck, chest, arm and waist.

In the second half of the $19^{\text {th }}$ century, replacing of national clothes primarily happened in the capital city, and further spread in the other territories of Azerbaijan. Traditional clothing completely lost out at the beginning of the $2 \mathrm{O}^{\text {th }}$ century due to its unsustainability to compete with mass-produced clothes.

Currently, when fashion designers prepare modern costumes they refer to the rich elements of our ancient clothing and apply them to their collections. Thus, they add historical national spirit to their clothing collections.

Keywords: Azerbaijan's Medieval clothes, types of fabric, $16^{\text {th }}$ century clothing, $18^{\text {th }}$ century dresses, gulabatin (golden embroidery), takalduz (tambour embroidery), Sequin sewing, European clothing, Art of Jewelry, Khatamkarlig, Minachilig.

\section{Introduction}

Clothing has passed long-term development path in Azerbaijan, as in other Eastern countries. In the Middle Ages, that the Great Silk Road passed through the territory of the Azerbaijan made an extensive contributions to the manufacture of clothing materials as much as its contributions to many other fields. With a high development of fabric manufacturing yet in the Early Middle Ages, many major cities became textile centers. During that period, linen fabrics exported to foreign countries and even ready-made garments of the highest quality were manufactured in Azerbaijan, along with wool and cotton fabrics. Samples of silk, velvet, zarfab woven with gold and silver threads and other fabrics, generally designed in Tabriz, Ardabil, Shamakhi, Ganja and other Azerbaijani cities at the time, are currently maintained in Moscow, Istanbul, Tabriz as well as many well-known museums (Efendiyev, 1971: 12). Delicate fabric samples that had been appraised highly back at the time were in demand in Venice, Netherlands
\end{abstract}

\footnotetext{
${ }^{*}$ Corresponding author

E-mail addresses: yegana.aghamaliyeva@gmail.com (Y. Aghamaliyeva)
} 
and Russia in all times (Dunyamaliyeva, 2013: 58). Fabric manufacturing in the $15^{\text {th }}$ century in Azerbaijan gave an impetus to the development of garments.

\section{Discussion}

The advancement of culture and art in Azerbaijan in the $16^{\text {th }}$ century contributed positively to the evolution of clothing. At that period, cloak (also called "aba") as overgarment, which was regarded as traditional dress was common in Azerbaijan. Relatively wealthy youths used to prefer putting on short-sleeved outer garments. They were mostly considered to be worn while either going hunting or going on a long trip.

Upper-class men in Azerbaijan used to wear brocade vests as overgarment. Additionally, they used to wear pants which are loose at the top but skinny on the legs. Pants were sewn with the same fabric used for production of over-shirt. At that time different types of shoes were produced. The most common men's footwear was knee-high boots in flat style that was made from supple leather. It was shoes amongst the most common footwear that the poor used to wear.

On the other side, there were various kinds of women's outer garments in Azerbaijan at that time. As men did, women used to wear long sleeve vests over the shoulders as an extra outfit element. Such vests were embroidered with fewer patterns, to ensure its plainness. Women used to wear long kamis shirt under the vest, reaching down to the bottom. Shirts were buttoned up with large buttons on the collar. Women used to hold the bottom part of their long dresses while walking. Embroidered head clothes, small and fine patterned taqiyah, delicate beaded petals, crown, head wraps etc. were existed for women in the $16^{\text {th }}$ century.

Contrary to the $16^{\text {th }}$ century, fabrics and outfits were of lower quality in the $17^{\text {th }}$. Regardless of the existence of fabric manufacturing and pallor ornaments at that time, wearing styles were generally reminiscent of outfits common in the $16^{\text {th }}$ century.

Until to the middle of the $18^{\text {th }}$ century, wearing style in Azerbaijan had developed almost in the same level. Azerbaijani men used to wear a long sleeve Chukha sitting tight to the body in the $18^{\text {th }}$ century. Being contrast to the previous periods, aba wearing was the preference of prominent and elderly people. Additionally, in the coldest parts of Azerbaijan, ideally in the winter they used to wear shearling coat, as beautifully fabricated, over which patterns through vibrant silk threads were used from the collar to its bottom part.

Arkhalig that was a long tight-waist jacket were worn under the Chukha, aba and shearling coat. A beautifully set arkhaligs were ornamented with golden or silver threads with a delicate pleasure. Arkhalig was fastened with circular buttons or galloons from the front. Most times waist lane was closely fitted at the waist.

At that time men's favorite adornment was regarded to be the ring and the dagger attached to the waist, distinguished by high artistic composition. Until the middle of the $19^{\text {th }}$ century, long head-dress, namely shish papag made from lamb skin was the most widely used among men. To enhance an aesthetic view of such head-dress, precious fabric was wrapped to its bottom.

At that period, women garments were fabricated in a more beautiful, delicate and specific style rather than men garments. In the $18^{\text {th }}$ century women put on long sleeve, short chapkan, arkhalig reaching down to the bottom, kurdu, neck, sleeves and laps of which were of fur, or kulaja. To make the shape look beautiful, below at its sides were bulging.

Arkhalig was the most popular cloth among women. Some archaligs were cut wide and straight with slits on its sides. They were designed in a style to ensure a smooth move of arms and prevent to perspire in hot weather. The neck, the collar, and the lap of kurdu were covered with fur, since it was worn in the winter. Women dressed long and wide sleeve shirt under such outer garments, which was made from silk for elite women, while it was made from cheap cotton goods for women in poverty. The shirts worn by women were of various colors according to the age limit (the youth preferred yellow and red floral fabrics, while the elderly women used dark fabrics). In the $18^{\text {th }}$ century, women wore tuman one after the other.

Women's shoes bore a resemblance to some men's shoes according to their shapes. Women used to wear bashmags or high-boots, both decorated in fancywork.

At that time, soft and fine feminine clothing having richly ornamental composition is currently maintained in National Art Museum of Azerbaijan. 
In the middle Ages, garments mainly were decorated in fancywork. To make compositions of fancyworks more lavish and exquisite, ganovuz, velvet fabrics, local silk and cotton threads, chakmapilaks (embroidery with sparkles) and gold and silver threads dust beads, string exported from abroad were used.

Clothing and jewelry were decorated with patterns featuring fauna including different species of birds, along with botanical and geometrical ornaments in unique compositions complementing each other. Ornaments used for women's garments were circular, or the around of which was frilling, while the inside was entire embroidered, depending on fabric types and cuts. Such compositions were used while making embroidery on hear-dresses. Fancy works presenting patterns of national ornaments consisted of gulabatin (golden embroidery), takalduz (tambour embroidery), gullabduz (loose stitch), scaly filling, shebeke etc.

Different kinds of sewing techniques, namely, gulabatin (golden embroidery) are one of the ancient techniques historically. In the Middle Ages, gulabatin (golden embroidery) stitchwork and embriodery highly advanced in Azerbaijan. Nizami Ganjavi, Molla Panah Vagif and people's ashugs repeatedly highlighted this art in their works. For gulabatin (golden embroidery), relatively dense and sustainable fabrics were used. For such embroidery, golden threads brought from Western and Eastern countries through trade routes were applied. Such stitchwork was applied onto fabric based on some methods. The most common method was stumpwork. The pattern feature of gulabatin (golden embroidery) was that it was ornamented with silhouette. Designing fine-lined patterns was achieved by highly talented artists, and thus, they managed to create an example of art. Associating golden threads with delicate, colored silk threads, master made the item more exquisite. The patterns of gulabatin (golden embroidery) were distinct from each other depending on the regions of Azerbaijan.

In the Middle Ages, takalduz (tambour embroidery) items based on the ornamental compositions was as much preferred as gulabatin (golden embroidery) items in the foreign markets. This kind of embroidery was applied for different coverings, as well as men's clothes, along with women's ones. Symmetry stitching of takalduz (tambour embroidery) patterns over the sewing part in the outer and head dresses and selection of colors with exceptional artistic taste are really fascinating. Through takalduz (tambour embroidery) featuring botanical themes and bird icons as specifically designed and clambering each other, ornaments stitched over women's garments were distinguished with its mysterious color and composition harmony. The other peculiarity of takalduz (tambour embroidery) was that an extraordinary diversity of colors gave an impression of many embroidered motifs, although plethora of patterns was reached as a result of successful combination of different colored threads. For takalduz (tambour embroidery), local and exported cloth fabric in red, black, dark and bright colors were used. Composite type of decoration as well as having an exquisite appearance was applied over dark-colored fabric by using silk threads in pleasant colors. Takalduz (tambour embroidery) was stitched through the so-called hook (type of needle), which was called gullabduz.

Another type of sewing - is Sequin sewing mostly used to enhance aesthetic appearance of the Aristocratic ladies' clothes. While sewing with sequins, the method of sewing the small bright metal circles of different colors on the pattern drawn on the fabric in advance was used (Efendiyev, 1961: 159, 167-168). There was small hole in the center of a sequin to fix to the clothes. It was widely spread to decorate women's clothing with sequins in Shamakhi, Shaki, Ganja, Nakhchivan and other cities. A variety of women clothing accessories like headscarves, purses and etc. were embroidered with sequins. Floral, bird and animal ornaments were used in the patterns of sequin sewing. Sequin Sewing was always in harmony with other embroideries such as gulabatin (golden embroidery), takalduz (tambour embroidery) and etc. The ornaments of high rank wealthy women's dresses were almost distinguished for being applied of all types of sewing with grate proficiency and taste. Traditional clothing set was completed by jewelries considered for neck, chest, arm and waist.

In the middle ages embroidery products were made of gold and silver, and precious stones such as brilliant, diamond, emerald, ruby, pearl, turquoise, agate and etc. were used. Baku, Ganja, Shamakhi, Shaki, Nakhchivan, Shusha were approved as jewelry centers of Azerbaijan. Local jewelers prepared all kind of jewelry that people need. Women loved adornment very much, and used them competently (Mammadova et al.: 40). Women of Upper Class had on head-dresses made of gold and silver, and decorated with various gemstones. The head-dresses were decorated 
with flowers and ornaments consisting of curly lined branches. Sometimes ruby, turquoise, diamonds and other stones and pearls were placed in the small nests among those ornaments. That technique added a particular beauty to clothing accessories.

In the $18^{\text {th }}$ centuries Azerbaijani women used neck adornment items more. Such adornment items were made by binding valuable beads, baklava and barley shaped gold and silver pieces to each other. The set of adornment items used by women was named as "imarat". It included different kinds of accessories for head and chest, rings, earrings, belt, bangle and bracelets.

Belt was a more widely spread jewelry product used by both women and men. With that accessory it was possible to identify its owner's position, wealth and nationality, even age. Usually wide belt was used by women, and thinner one by men.

It should be noted that produced jewelries were decorated by six technical methods: I - forging, II - metal spinning, III - garasavad, IV - shebeke, V - Minachilig and VI Khatemkarlig (Mammadova et al., 2009: 41).

Khatemkarlig has a great heritage in the field of Azerbaijan Jewellry Art. To write and draw a picture on jewelries with a variety of ornamental compositions using precious metals, the item is holed slightly, and the holes were filled with gold and silver colored metals. After all mentioned processes finished, the surface of the object was polished and beautiful mosaic appeared.

Minachilig (enameling) is one of the jewellry art areas raising it to higher level. The method of minachilig is filling a carved image, ornament with liquid enamel. Through Azerbaijan enameling has been mostly used in Nakhchivan and Baku. Yet, in the $18^{\text {th }}$ century the high quality Baku enamels were ranking first over the World Market. In Azerbaijan enameling (minachilig) leaf-shaped floral ornaments and green, black, blue, red colored enamels were used. This method is widely used in modern art of jewelry.

In the $19^{\text {th }}$ century development of the oil industry in Azerbaijan makes the traditional clothing change gradually. In the cities western tendencies have already influenced to the traditional clothes. The "old cloths" being lost out day by day are replaced with the new, simple, unadorned clothes made of cheap fabrics exported from Russia. European clothes, gradually spreading to the regions and from there to the villages cause the national clothing to entirely fade away. In the middle of the $19^{\text {th }}$ century among the clothing of aristocrat ladies of Azerbaijan , new ornaments such as lace, pleat etc. appear, that affect the overall shape of the traditional clothes and change it. Women now wear shoes imported from European countries (Dunyamaliyeva, 2013, p.105-107).

Meanwhile, in the second half of the $19^{\text {th }}$ century, replacing of national clothes primarily happened in the capital city, and further spread in the other territories of Azerbaijan. Traditional clothing completely lost out at the beginning of the $20^{\text {th }}$ century due to its unsustainability to compete with mass-produced clothes. However, we can still find fragments of our traditional clothing in some regions and villages of Azerbaijan.

\section{Conclusion}

So, we conclude that the clothes art as the other areas of the decorative art, despite its venerable age, is forced to seek ways of creative development and form new approaches (Zharkova, 2015: 106-112). The art of clothes is the most important factor in the development of the folk culture, ordering the primordial sources of the spiritual life of the people, demonstrating its moral, aesthetic values (Nekrasova, 1983: 35-40). Currently, when fashion designers prepare modern costumes they refer to the rich elements of our ancient clothing and with this prefer to add historical national spirit to their collections.

\section{References}

Mammadova et al., 2009 - Mammadova L.H., Aghamaliyeva Y.C., Pashayev B.S. (2009). History of Fashion and Costumes, Baku, Publishing House, 218 p.

Efendiyev, 1971 - Efendiyev R. (1971). People's art in Azerbaijan, Azerbaijan State Publishing, Baku, 397 p.

Efendiyev, 1961 - Efendiyev R. (1961). Decorative and applied art of Azerbaijan costumes of the 16th-18th centuries, Leningrad (autoreferat of Ph.D thesis).

Dunyamaliyeva, 2013 - Dunyamaliyeva S.S. (2013). Art-decorative Characteristics of the 
Azerbaijan clothes, Baku, Elm, 448 p.

Zharkova, 2015 - Zharkova A.A. (2015). Paradigmatic approach to the socio-cultural activity of youth in the current ситуатион, Bulletin of the Moscow State University of Culture and Arms, 3 (59): 106-112.

Nekrasova, 1983 - Nekrasova M.A. (1983). Folk art as a part of culture: Theory and practice, Moscow, Fine Arts, 343 p.

Kerimov, 1992 - Kerimov K. (1992). Art of Azerbaijan, Baku.

Veliyev, 1990 - Veliyev F.I. (1992). Material culture of the western zone of Azerbaijan in the 21st-20th centuries, Leningrad.

Pashayev, 2004 - Pashayev B.S. (2004). The art design, the artistic design of textile and clothing, Baku, Elm, 354 p.

Gorina, 1994 - Gorina G.S. (1994). Folk traditions in modeling clothes. Moscow, Lengpromizdat.

Sadikhzade, 1971 - Sadikhzade Sh. (1971). Ancient jewelry of Azerbaijan, Baku, Elm, 79 p. 